\title{
Effects of Mono- and Divalent Cations on the Properties of Multicomponent Phosphate Glasses
}

\author{
Heiji TABUCHI, Nobuya KURIYAMA and Shigeki MORIMOTO \\ Glass Research Center, Central Glass Co., Ltd., 1510, Ohkuchi-cho, Matsusaka-shi, Mie 515 \\ 多成分リン酸塩ガラスの性質に及ぼす 1 価及び 2 価イオンの影響 \\ 田淵平次・栗山延也・森本繁樹 \\ セントラル硝子(株)硝子研究所, 515 三重県松阪市大口町 1510
}

[Received June 20, 1994; Accepted November 22, 1994]

\begin{abstract}
The effects of mono- and divalent cations on the properties of multicomponent phosphate glasses with the compositions of $10 \mathrm{PbO} \cdot 20 \mathrm{ZnO} \cdot 10 \mathrm{R}_{2} \mathrm{O} \cdot 50 \mathrm{P}_{2} \mathrm{O}_{5} \cdot 7.5 \mathrm{Al}_{2} \mathrm{O}_{3}$. $2.5 \mathrm{~B}_{2} \mathrm{O}_{3}$ (R: $\left.\mathrm{Li}, \mathrm{Na}, \mathrm{K}, \mathrm{Rb}\right)$ and $10 \mathrm{PbO} \cdot 20 \mathrm{ZnO} \cdot 5 \mathrm{Li}_{2} \mathrm{O}$. $5 \mathrm{R}^{\prime} \mathrm{O} \cdot 50 \mathrm{P}_{2} \mathrm{O}_{5} \cdot 7.5 \mathrm{Al}_{2} \mathrm{O}_{3} \cdot 2.5 \mathrm{~B}_{2} \mathrm{O}_{3}\left(\mathrm{R}^{\prime}: \mathrm{Mg}, \mathrm{Ca}, \mathrm{Sr}, \mathrm{Ba}\right.$, $\mathrm{Zn}, \mathrm{Cd}, \mathrm{Sn}, \mathrm{Pb})$ were investigated. Glass transition temperature $\left(T_{\mathrm{g}}\right)$, yielding point $\left(\boldsymbol{Y}_{\mathrm{p}}\right)$, and thermal expansion coefficient $(\alpha)$ increased with increasing ionic radius of the alkali ion. As a result, water durability of the phosphate glass was highly improved. Introduction of divalent cations also resulted in the same tendency. It was considered that the improvement of the water durability was due to the increasing linking density, which was accompanied by increasing steric hindrance of additional cations against attack by water molecules.
\end{abstract}

Key-words : Phosphate glass, Linking density, Coordination number, Steric hindrance, FT-IR, Water durability

\section{Introduction}

Recently, new solder glass having a lower working point and a higher chemical durability is required because of the marked development of electronics. Although phosphate glass is one of the candidates of such low-melting temperature glass, it is so unstable in water that there is little possibility for its application as the soldering material for electric parts. However, phosphate glass with a low melting temperature has a high potential for use instead of solder glass containing a large amount of $\mathrm{PbO}$, which is considered to cause serious environmental problems. ${ }^{1)-5)}$

We have studied the effects of several ions on the properties of phosphate glasses from the viewpoints of a lowering of the melting point and an improvement of the water durability. ${ }^{6)}$

It is well known that the introduction of $\mathrm{Al}^{3+}$ to phosphate glass improves the water durability. $\left.{ }^{7}\right)$ This improvement is explained by the cross-linking of the phosphate chains by 4 -fold or 6 -fold $\mathrm{Al}^{3+}$ ions with cleavage of the $\mathrm{P}=\mathrm{O}$ double bond. It was found that the 6 -fold $\mathrm{Si}^{4+}$ ions make the glass more stable in water than do the 4 -fold ones. ${ }^{6}$ )
Phosphate glass has a one- or two-dimensional glass network like an organic polymer, which is in contrast to the three-dimensional glass networks of silicate and borate glasses. Therefore, the chemical durability of phosphate glass will be strongly influenced by the linking strength between the phosphate chains and the local structure around the linking cations.

In this paper, the effect of mono- and divalent modifier ions on the properties, especially on water durability, was investigated in multicomponent phosphate glasses.

\section{Experimental procedure}

Glass samples were prepared by the conventional melting method. The base compositions of phosphate glasses are $10 \mathrm{PbO} \cdot 20 \mathrm{ZnO} \cdot 10 \mathrm{R}_{2} \mathrm{O} \cdot 50 \mathrm{P}_{2} \mathrm{O}_{5}$. $7.5 \mathrm{Al}_{2} \mathrm{O}_{3} \cdot 2.5 \mathrm{~B}_{2} \mathrm{O}_{3} \quad(\mathrm{R}: \mathrm{Li}, \mathrm{Na}, \mathrm{K}, \mathrm{Rb})$ and $10 \mathrm{PbO} \cdot 20 \mathrm{ZnO} \cdot 5 \mathrm{Li}_{2} \mathrm{O} \cdot 5 \mathrm{R}^{\prime} \mathrm{O} \cdot 50 \mathrm{P}_{2} \mathrm{O}_{5} \cdot 7.5 \mathrm{Al}_{2} \mathrm{O}_{3} \cdot 2.5$ $\mathrm{B}_{2} \mathrm{O}_{3}\left(\mathrm{R}^{\prime}: \mathrm{Mg}, \mathrm{Ca}, \mathrm{Sr}, \mathrm{Ba}, \mathrm{Zn}, \mathrm{Cd}, \mathrm{Sn}, \mathrm{Pb}\right)$. Aluminum metaphosphate $\left(\mathrm{Al}\left(\mathrm{PO}_{3}\right)_{3}\right)$, boron phosphate $\left(\mathrm{BPO}_{4}\right)$, orthophosphoric acid $\left(\mathrm{H}_{3} \mathrm{PO}_{4}\right)$, red lead $\left(\mathrm{Pb}_{3} \mathrm{O}_{4}\right)$, zinc white $(\mathrm{ZnO})$, and lithium carbonate $\left(\mathrm{Li}_{2} \mathrm{CO}_{3}\right)$ of guaranteed reagent grade were weighed in desired proportions so as to obtain 200-g glass samples. $\mathrm{R}_{2} \mathrm{O}$ and $\mathrm{R}^{\prime} \mathrm{O}$ were introduced as oxide or carbonate. The mixtures were calcined at $500^{\circ} \mathrm{C}$ for $1 \mathrm{~h}$ in a $500-\mathrm{ml} \mathrm{Pt} \mathrm{crucible} \mathrm{to} \mathrm{eliminate} \mathrm{H}_{2} \mathrm{O}$ prior to melting. Then they were heated at $1100-1300^{\circ} \mathrm{C}$ for $1 \mathrm{~h}$, depending on the chemical composition. After being stirred, each melt was poured onto a graphite plate and then gradually cooled from $400^{\circ} \mathrm{C}$ to room temperature in a $\mathrm{SiC}$ electric furnace. Visual observation was made in order to check the devitrification of the final products. Glass transition temperature $\left(T_{\mathrm{g}}\right)$, yielding point $\left(Y_{\mathrm{p}}\right)$, and thermal expansion coefficient $(\alpha)$ were determined using a Rigaku differential thermal dilatometer, model TAS8140, at a heating rate of $5 \mathrm{~K} / \mathrm{min}$. Densities were measured by the Archimedes method. Water durability was evaluated by the powder method. Infrared (IR) spectra were recorded on a Nicolet Fourier-transform infrared (FT-IR) spectrometer, model 510 , using $\mathrm{KBr}$ pellets containing 0.5 mass $\%$ glass concentration. 
Details of the measurements were described elsewhere.6)

\section{Results}

Physical properties and water durability of glasses are summarized in Table 1. Devitrification was observed in the SnO-containing glass. The value of $\alpha$ increased with increasing ionic radii of $\mathrm{R}$ and $\mathrm{R}^{\prime}$ in almost all the glass systems. The values of $T_{\mathrm{g}}$ and $Y_{\mathrm{p}}$ increased with increasing ionic radius of the alkali ion, except in the case of $\mathrm{Rb}_{2} \mathrm{O}$-containing glass. On the other hand, $T_{\mathrm{g}}$ and $Y_{\mathrm{p}}$ did not change drastically in the divalent-cation-containing glasses. Water durability $(-\Delta)$ was improved with increasing cation radius, except for the glasses containing cations with very large ionic radii.

The relationship between $T_{\mathrm{g}}$ and $\alpha$ of phosphate glasses studied here is shown in Fig. 1. For the introduction of divalent cations into the glass, $\alpha$

Table 1. Physical Properties of Phosphate Glasses

\begin{tabular}{|c|c|c|c|c|c|c|}
\hline $\begin{array}{l}\text { Glass } \\
\text { System }\end{array}$ & 0xide & $\begin{array}{c}\mathrm{Tg} \\
\left({ }^{\circ} \mathrm{C}\right)\end{array}$ & $\begin{array}{l}Y p \\
\left({ }^{\circ} \mathrm{C}\right)\end{array}$ & $\begin{array}{c}\alpha \\
\left(10^{-7} K^{-1}\right)\end{array}$ & $\begin{array}{l}\rho \\
\left(10^{3} \mathrm{~kg} \mathrm{~m}^{-3}\right)\end{array}$ & $\begin{array}{l}-\Delta * \\
\text { (mass } \%)\end{array}$ \\
\hline I & $\begin{array}{l}\mathrm{Li}_{2} \mathrm{O} \\
\mathrm{Na}_{2} \mathrm{O} \\
\mathrm{K}_{2} \mathrm{O} \\
\mathrm{Rb}_{2} \mathrm{O}\end{array}$ & $\begin{array}{l}376 \\
388 \\
410 \\
402\end{array}$ & $\begin{array}{l}429 \\
446 \\
473 \\
462\end{array}$ & $\begin{array}{r}92.2 \\
100.2 \\
102.2 \\
102.9\end{array}$ & $\begin{array}{l}3.231 \\
3.253 \\
3.196 \\
3.365\end{array}$ & $\begin{array}{l}1.61 \\
1.42 \\
1.52 \\
0.67\end{array}$ \\
\hline II & $\begin{array}{l}\mathrm{Li}_{2} 0 \\
\mathrm{Mg} 0 \\
\mathrm{Ca} 0 \\
\mathrm{Sr} 0 \\
\mathrm{Ba} 0\end{array}$ & $\begin{array}{l}376 \\
403 \\
397 \\
397 \\
400\end{array}$ & $\begin{array}{l}429 \\
458 \\
457 \\
456 \\
462\end{array}$ & $\begin{array}{l}92.2 \\
82.5 \\
86.2 \\
87.2 \\
89.5\end{array}$ & $\begin{array}{l}3.231 \\
3.206 \\
3.226 \\
3.288 \\
3.336\end{array}$ & $\begin{array}{l}1.61 \\
2.10 \\
1.40 \\
0.79 \\
1.08\end{array}$ \\
\hline & $\begin{array}{l}\text { Zno } \\
\text { Cd0 }\end{array}$ & $\begin{array}{l}386 \\
387\end{array}$ & $\begin{array}{l}446 \\
449\end{array}$ & $\begin{array}{l}82.7 \\
83.8\end{array}$ & $\begin{array}{l}3.254 \\
3.330\end{array}$ & $\begin{array}{l}3.09 \\
1.10\end{array}$ \\
\hline & $\begin{array}{l}\text { SnO } \\
\text { PbO }\end{array}$ & \multicolumn{5}{|c|}{ Crystallization } \\
\hline
\end{tabular}

I : $10 \mathrm{PbO} \cdot 20 \mathrm{ZnO} \cdot 10 \mathrm{R}_{2} \mathrm{O} \cdot 50 \mathrm{P}_{2} \mathrm{O}_{5} \cdot 7.5 \mathrm{Al}_{2} \mathrm{O}_{3} \cdot 2.5 \mathrm{~B}_{2} \mathrm{O}_{3}$ II : $10 \mathrm{PbO} \cdot 20 \mathrm{ZnO} \cdot 5 \mathrm{Li}_{2} \mathrm{O} \cdot 5 \mathrm{R}^{\prime} 0 \cdot 50 \mathrm{P}_{2} \mathrm{O}_{5} \cdot 7.5 \mathrm{Al}_{2} \mathrm{O}_{3} \cdot 2.5 \mathrm{~B}_{3} \mathrm{O}_{3}$ *:Water Durability $\left(95^{\circ} \mathrm{C}-20 \mathrm{~h}\right.$, Weight Loss)

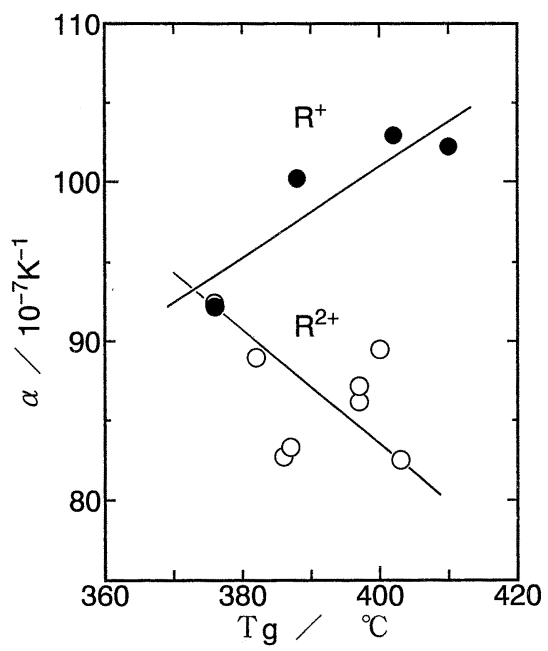

Fig. 1. The relationship between the thermal expansion coefficient $(\alpha)$ and the glass transition temperature $\left(T_{\mathrm{g}}\right)$ of the various phosphate glasses. decreased with an increasing $T_{\mathrm{g}}$, as is generally observed in several kinds of glasses. On the other hand, it was found, in monovalent-cation-containing glasses, that $\alpha$ increased with increasing $T_{\mathrm{g}}$.

The infrared (IR) spectra of the phosphate glasses containing different alkali cations are shown in Fig. 2 in the wave number region ranging from 400 to $1400 \mathrm{~cm}^{-1}$. It was found that the absorption peak at around $1100 \mathrm{~cm}^{-1}$ becomes broad and shifts to a higher-wave number region with increasing ionic radius of the alkali ion $(R)$. The IR spectra of phosphate glasses containing different alkaline-earth cations are shown in Fig. 3. There is no appreciable

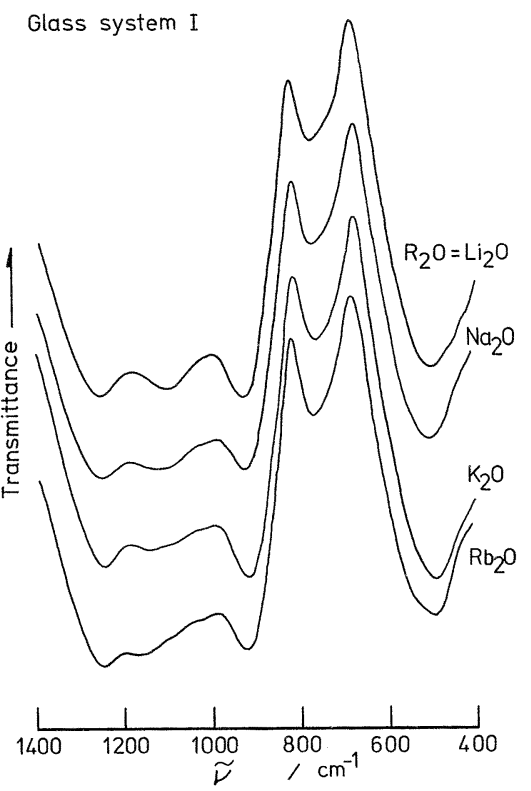

Fig. 2. The IR spectra of phosphate glasses containing different alkali ions.

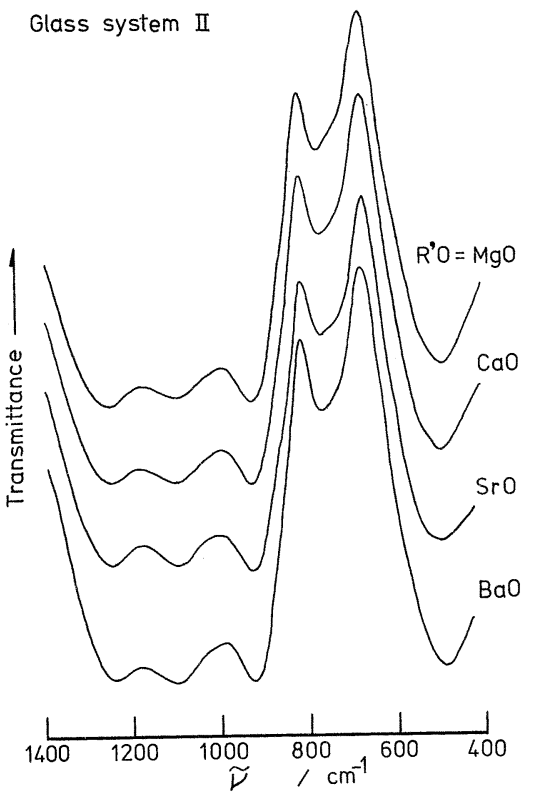

Fig. 3. The IR spectra of phosphate glasses containing different alkaline-earth ions. 
change in the absorption peaks by the introduction of alkaline-earth cations $\left(\mathrm{R}^{\prime}\right)$.

\section{Discussion}

In general, it is known that the water durability of phosphate glass is improved by the introduction of a network modifier, which is quite different from the case of silicate and borate glasses. ${ }^{1)}$ It is due to the $\mathrm{P}=\mathrm{O}$ double bond in the phosphate glasses. There are two mechanisms proposed for the hydration of phosphate glass: one is the hydration of covalent $\mathrm{P}-$ $\mathrm{O}-\mathrm{P}$ bonds and the other is the hydration of the ionic bond between modifier cations and oxygen, resulting in cleavage of the linkage between phosphate chains. The $\mathrm{PO}_{4}$ group bonded to three $\mathrm{PO}_{4}$ units will be easily disrupted by water. In phosphate-rich glasses, cross-link hydrolysis will occur easily, forming a loosely bound network of linear phosphate chains which can be rapidly dissolved in water. ${ }^{8)}$

Modifier-rich phosphate glasses consist of waterresistant linear phosphate chains which are linked to each other by ionic bonds. In this case, water will disrupt the ionic bonds easily. Therefore, the water durability of such glasses will be governed by the strength of the ionic bonds as well as by the degree of cross-linking.

It is also well known that $\mathrm{Al}^{3+}$ and $\mathrm{B}^{3+}$ are very effective cations for fortifying the structure of phosphate glasses. This is interpreted from the formation of silica like $\mathrm{AlPO}_{4}$ and $\mathrm{BPO}_{4}$ glass structures. ${ }^{7)}$ The bond strength of $\mathrm{P}-\mathrm{O}$ and $\mathrm{Al}-\mathrm{O}$ bonds is as high as that of $\mathrm{Si}-\mathrm{O}$, whereas the bond strength of $\mathrm{B}-\mathrm{O}$ is slightly lower than those of $\mathrm{P}-\mathrm{O}$ and $\mathrm{Al}-\mathrm{O}$ bonds. It is seen from Table 1 that the water durability tends to be improved by the introduction of larger cations. This can be explained by the change of the coordination number (or linking density) around the additional cations.

The average coordination number ${ }^{9)}$ of mono- and divalent cations in the various glasses is listed in Table 2. In general, when the ionic radius becomes large, the coordination number is increased. A larger cation can be linked with a large number of phosphate chains, and consequently, the structure of phosphate glass would become more rigid. On the

Table 2. Coordination Numbers $(\mathrm{CN})$ of Cations in Glasses ${ }^{9)}$

\begin{tabular}{cc}
\hline Cation & \multicolumn{2}{c}{$\mathrm{CN}$} \\
\hline $\mathrm{Li}$ & $4, \quad 6$ \\
$\mathrm{Na}$ & $6, \quad 8$ \\
$\mathrm{~K}$ & $6,10,12$ \\
$\mathrm{Rb}$ & 10,12 \\
$\mathrm{Mg}$ & $4, \quad 6$ \\
$\mathrm{Ca}$ & $6, \quad 8$ \\
$\mathrm{Sr}$ & $6, \quad 8,12$ \\
$\mathrm{Ba}$ & 8,12 \\
$\mathrm{Zn}$ & $4, \quad 6$ \\
$\mathrm{Cd}$ & $6, \quad 8$ \\
$\mathrm{~Pb}$ & $6, \quad 8$ \\
\hline
\end{tabular}

contrary, the single-bond strength between linking cations and phosphate chains will be decreased. These two opposing factors affect the properties of phosphate glasses. In Table 1 , the value of $\alpha$ increases with increasing ionic radius of additional cations. This indicates that the introduction of large cations weakens the mean bond strength. The increase of the $\alpha$ value usually results in a lowering of the $T_{\mathrm{g}}$ and $Y_{\mathrm{p}}$ values. In the glass system $\mathrm{I}, \alpha$ is proportional to $T_{\mathrm{g}}$.

Figure 2 shows that the absorption peak observed at around $1100 \mathrm{~cm}^{-1}$ becomes broad and also shifts to a higher-wave number region with an increasing ionic radius of the alkali ion. This absorption peak is assigned to the $\mathrm{P}^{-} \mathrm{O}^{-}$stretching vibration. It is understood on the basis of Fig. 2 that the $\mathrm{P}-\mathrm{O}^{-}$bond is strengthened by the introduction of larger cations. This is in contrast to the change of $\alpha$. On the other hand, in the glass system II, no appreciable change of the absorption peak was observed, as shown in Fig. 3.

In the phosphate glasses discussed here, it was confirmed that the phosphate network was fortified by the larger cations. This indicates that an increase in the amount of cross-linking is a dominant factor in the fortification of the phosphate network. These results are consistent with the results obtained by $\mathrm{He}$ and Day ${ }^{10)}$ in different phosphate glasses.

The change of the local structure will be related to the decrease in the "space" which is attacked by the water molecules, especially when the coordination number of cations is large. In such a case, it will be difficult for the water molecules to attack the crosslinking cations. Thus, the improved water durability of the phosphate glasses can be explained by the increasing steric hindrance around the cations.

\section{Summary}

The effects of mono- and divalent cations on the properties of multicomponent phosphate glasses were investigated. The $T_{\mathrm{g}}, Y_{\mathrm{p}}$ and $\alpha$ were increased with increasing ionic radius of the alkali ion. As a result, the water durability of the phosphate glasses was improved. An introduction of divalent cations also resulted in the same tendency. It is evident from the IR measurement that the coordination number of cross-linking cations is increased with increasing ionic radius of the cation, and as a result, the bonding strength between cations and oxygen was weakened. It is considered that the improvement of the water durability is due to the increasing linking density, which is accompanied by increasing steric hindrance of the additional cations against attack by water molecules.

\section{References}

1) M. A. Tyndyala and W. R. Ott, Am. Ceram. Soc. Bull., 57, 432-37 (1978).

2) J. M. Clinton and W. W. Coffeen, Am. Ceram. Soc. Bull., 63, 1401-04 (1984). 
3) N. H. Ray, J. N. C. Laycock and W. D. Robinson, Glass Technol., 14, 50-59 (1973)

4) Y. B. Peng and D. E. Day, Glass Technol., 32, 166-73 (1991).

5) Y. B. Peng and D. E. Day, Glass Technol., 32, 200-05 (1991).

6) H. Tabuchi, N. Kuriyama and S. Morimoto, J. Ceram. Soc.
Japan, 102, 221-24 (1994).

7) B. C. Bunker, G. W. Arnold, R. Rajaram and D. E. Day, J. Am. Ceram. Soc., 70, 425-30 (1978).

8) A. Kishioka, Bull. Chem. Soc. Jpn., 50, 2088-92 (1977).

9) A. A. Appen, "The Chemistry of Glass (in Russian)", Izd. Chimia, Leningrad (1970).

10) Y. He and D. E. Day, Glass Technol., 33, 214-19 (1992). 